\title{
AISI 1005 Steel Plasma Treated by Different Thermochemical Surface Treatments
}

\author{
Keli Vanessa Salvador Damin ${ }^{a, b *}$, Thiago de Souza Lamim ${ }^{a}$, Francisco Cavilha Neto $^{a}$, Cristiano Binder ${ }^{a}$,
}

Aloisio Nelmo Klein ${ }^{a}$, Ana Maria Maliska ${ }^{a}$

\author{
${ }^{a}$ Mechanical Engineering Department, Federal University of Santa Catarina - UFSC, 88040-900, \\ Florianópolis, SC, Brazil \\ ${ }^{b}$ Technical Department in Mechanical, Federal Institute of Santa Catarina - IFSC, 89813-000, \\ Chapecó, SC, Brazil
}

Received: October 3, 2015; Revised: February 3, 2016; Accepted: July 13, 2016

To modify the surface structure of AISI 1005 steel and its properties without any dimensional loss, different plasma surface treatments were performed at low temperatures $\left(500{ }^{\circ} \mathrm{C}\right)$ in this study. The samples were subjected to single plasma treatments including: nitriding (N5\% and N3\%), carburizing (CE) and ferritic nitrocarburizing (NC) and to duplex treatments of nitriding followed by carburizing $(\mathrm{N} 5 \%+\mathrm{CE}$ and $\mathrm{N} 3 \%+\mathrm{CE})$ and ferritic nitrocarburizing followed by carburizing $(\mathrm{NC}+\mathrm{CE})$. The gas mixture used for these treatments was varied as follows: nitriding $\left(5 \% \mathrm{~N}_{2}+95 \% \mathrm{H}_{2}\right.$ and $\left.3 \% \mathrm{~N}_{2}+97 \% \mathrm{H}_{2}\right)$, carburizing $\left(5 \% \mathrm{CH}_{4}+95 \% \mathrm{H}_{2}\right)$ and ferritic nitrocarburizing $\left(5 \% \mathrm{~N}_{2}+1.5 \% \mathrm{CH}_{4}+93.5 \% \mathrm{H}_{2}\right)$. A microstructural characterization of the samples was carried out using optical and scanning electron microscopy in addition to XRD analysis. Microhardness testing was also performed. The XRD analysis showed a stabilization of the outermost cementite layer for all of the carburizing treatments. The results show that a greater hardness increase was achieved for the nitriding treatment as well as a more regular compound layer. However, a greater depth of hardening was obtained in samples with $\mathrm{NC}+\mathrm{CE}$ and $\mathrm{N} 5 \%+\mathrm{CE}$, which extended to the hardened depth to $800 \mu \mathrm{m}$.

Keywords: Plasma Carburizing, Plasma Nitriding, Plasma Ferritic Nitrocarburizing

\section{Introduction}

In recent decades, there have been constant advancements in the techniques used for surface modifications of materials. The importance of such techniques is linked to the fact that modifications of the surface properties enable new applications for materials due to changes in the chemical, physical, mechanical, metallurgical and tribological properties ${ }^{1-5}$. Among these techniques is a plasma surface thermochemical treatment.

Nitriding is a thermochemical treatment in which the hardening of a surface is achieved by introducing nitrogen through exposure in a nitriding Atmosphere, which permits the formation of nitrides ${ }^{3,6,7}$. Nitriding is performed at temperatures within the ferritic phase $\left(500-570{ }^{\circ} \mathrm{C}\right)$ making the subsequent quenching treatment used to increase the hardness unnecessary ${ }^{8}$. The same applies for the ferritic nitrocarburizing process, which differs only in the composition of the atmosphere containing the carbon.

Carburizing is also a surface treatment utilizing carbon diffusion. Generally, for carbon steels, this treatment occurs normally above $900{ }^{\circ} \mathrm{C}$. However, for pieces that require high dimensional and geometric controls, the use of the high temperatures used in the carburizing treatment becomes a problem, as it leads to a loss of dimensional control ${ }^{9}$.

Carburizing treatments at low temperatures has been developed, as described $\mathrm{in}^{10-13}$, for stainless steels to avoid sensitization above $450{ }^{\circ} \mathrm{C}$ in these materials, and also for

*e-mail: kelivsd@gmail.com sintered pure iron and automobile gears, again, both to ensure dimensional control ${ }^{9,14}$. Furthermore, the literature contains some studies describing plasma carburizing at low temperatures as a method to produce surface layers of pure cementite ${ }^{15-18}$.

This work evaluates the layers obtained in AISI 1005 steel for different plasma surface treatments with regards to the structure, microstructure and hardness of the formed layers.

\section{Material and Methods}

The material used as a substrate in this study is AISI 1005 low carbon steel with a chemical composition shown in Table 1. The samples were discs with a diameter of 25.4 $\mathrm{mm}$ and a height of $6 \mathrm{~mm}$. All of the samples were ground, polished and cleaned in an acetone ultrasonic bath prior to the thermochemical treatments.

Seven different thermochemical treatments were carried out in a DC pulsed glow discharge reactor with the samples in the cathode configuration. Single plasma treatments including nitriding, carburizing ferritic nitrocarburizing and double treatments of nitriding followed by carburizing and ferritic nitrocarburizing followed by carburizing were performed. The parameters of these treatments and nomenclature used are presented in Table 2. The working temperature was reached using auxiliary heating and the cooling of the samples performed in the plasma environment. 
Table 1: Chemical composition of AISI 1005 (wt.\%).

\begin{tabular}{lllllll}
\hline $\mathrm{C}$ & $\mathrm{Si}$ & $\mathrm{Mn}$ & $\mathrm{P}$ & $\mathrm{S}$ & $\mathrm{Cr}$ & $\mathrm{Fe}$ \\
\hline 0,036 & $<0,002$ & 0,173 & 0,036 & 0,014 & 0,01 & balance \\
\hline
\end{tabular}

Table 2: Cycling and parameters of the treatments.

\begin{tabular}{|c|c|c|c|c|c|c|c|}
\hline Nomenclature & Treatment & Gas Mixture & $\begin{array}{l}\text { Pressure } \\
\text { (Torr) }\end{array}$ & $\begin{array}{l}\text { Time } \\
\text { (h) }\end{array}$ & $\begin{array}{l}\text { DDP } \\
\text { (V) }\end{array}$ & $\begin{array}{c}\text { Flow } \\
\left(\mathrm{cm}^{3} / \mathrm{min}\right)\end{array}$ & $\begin{array}{c}\text { Temperature } \\
\left({ }^{\circ} \mathrm{C}\right)\end{array}$ \\
\hline N5\% & Nitriding & $5 \% \mathrm{~N}_{2} / 95 \% \mathrm{H}_{2}$ & 3 & 3 & 500 & 240 & 500 \\
\hline N3\% & Nitriding & $3 \% \mathrm{~N}_{2} / 97 \% \mathrm{H}_{2}$ & 3 & 3 & 500 & 240 & 500 \\
\hline $\mathrm{NC}$ & Ferritic Nitrocarburizing & $5 \% \mathrm{~N}_{2} / 1.5 \% \mathrm{CH}_{4} / 93.5 \% \mathrm{H}_{2}$ & 3 & 3 & 500 & 240 & 500 \\
\hline $\mathrm{CE}$ & Carburizing & $5 \% \mathrm{CH}_{4} / 95 \% \mathrm{H}_{2}$ & 5 & 3 & 500 & 240 & 500 \\
\hline \multirow[t]{2}{*}{$\mathrm{N} 5 \%+\mathrm{CE}$} & Nitriding & $5 \% \mathrm{~N}_{2} / 95 \% \mathrm{H}_{2}$ & 3 & 3 & 500 & 240 & 500 \\
\hline & Carburizing & $5 \% \mathrm{CH}_{4} / 95 \% \mathrm{H}_{2}$ & 5 & 3 & 500 & 240 & 500 \\
\hline \multirow[t]{2}{*}{$\mathrm{N} 3 \%+\mathrm{CE}$} & Nitriding & $3 \% \mathrm{~N}_{2} / 97 \% \mathrm{H}_{2}$ & 3 & 3 & 500 & 240 & 500 \\
\hline & Carburizing & $5 \% \mathrm{CH}_{4} / 95 \% \mathrm{H}_{2}$ & 5 & 3 & 500 & 240 & 500 \\
\hline \multirow[t]{2}{*}{$\mathrm{NC}+\mathrm{CE}$} & Ferritic Nitrocarburizing & $5 \% \mathrm{~N}_{2} / 1.5 \% \mathrm{CH}_{4} / 93.5 \% \mathrm{H}_{2}$ & 3 & 3 & 500 & 240 & 500 \\
\hline & Carburizing & $5 \% \mathrm{CH}_{4} / 95 \% \mathrm{H}_{2}$ & 5 & 3 & 500 & 240 & 500 \\
\hline
\end{tabular}

Conventional metallography procedures were performed to analyze the microstructure and the layers. The samples were etched with a Nital $2 \%$ solution and the obtained microstructures were examined using optical (Olympus BX60M) and scanning electron microscopy (Hitachi TM 3030).

A Philips X-ray diffractometer (X'Pert MPD) with a copper $\mathrm{K} \alpha$ radiation source $(\lambda=1.5418 \AA)$ was used to determine the phases of the samples before and after the plasma treatments. The numbers of JCPDS cards used to identify the phases were: 03-065-2412 (cementite), 03-065-4899 $(\alpha-\mathrm{Fe})$ 01-077-2006 $\left(\mathrm{Fe}_{4} \mathrm{~N}\right)$ and 01-083$0879\left(\mathrm{Fe}_{3} \mathrm{~N}\right)$.

The mechanical properties were evaluated for surface microhardness using a Leco LM100AT with a Vickers indenter and a $0.01 \mathrm{~kg}$ load. For each treatment, a cut was made in the sample in the transverse direction to expose a surface for microhardness measurements to be made at different depths $(25,50,75,100,125,150,200,300,400$, $500,650,750$ and 800 micrometers) to statistically determine the substrate hardness. Hardness measurements were also performed on the sample surface.

The large number of measurements used for the microhardness tests were performed to ensure a maximum relative error of $10 \%$ and a reliability of $95 \%$. Analysis test hypotheses, estimation of variance and multiple comparisons of means were also performed.

\section{Results and discussion}

\subsection{Microstructure and X-ray diffraction}

Figure 1(a) shows a cross section of the AISI 1005 steel sample surface without any thermochemical treatments. We observe only the presence of the ferrite phase and a small fraction of pearlite in the microstructure, which is confirmed by the XRD pattern presented in Figures 1 (b) and (c).

Figure 2 (a) shows the surface microstructure of the sample after plasma carburizing (CE). We observe a thin carburized layer, which appears to be homogeneous along the entire surface. This layer may be related to the increase of the cementite peaks in the XRD patterns of this sample, as seen in Figure 2 (b). Thus, the plasma carburizing treatment promotes the formation of a thin $\mathrm{Fe}_{3} \mathrm{C}$ layer on the substrate.

The same result was seen in ${ }^{9}$, which is attributed to the formation of this thin layer of cementite because of the low diffusivity of carbon at $500{ }^{\circ} \mathrm{C}$, and the low solubility of these atoms in $\alpha-\mathrm{Fe}$, which is approximately 0.0025 wt. $\%$ at $500{ }^{\circ} \mathrm{C}$. From this, the adsorbed carbon atoms on the surface do not have enough mobility to diffuse into the substrate, causing saturation of the element on the surface, and therefore, the precipitation of cementite.

Figure 3 (a) shows the layer after a single treatment of plasma nitriding with $5 \% \mathrm{~N}_{2}(\mathrm{~N} 5 \%)$. It is possible that this treatment promotes the formation of a compound and 


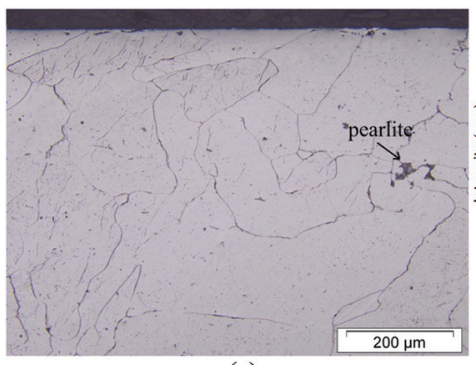

(a)

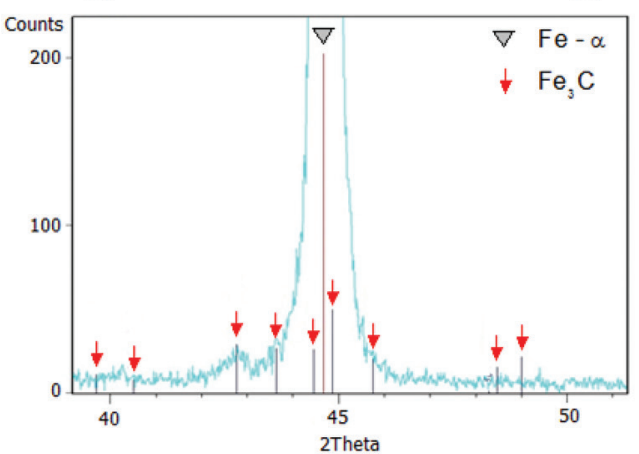

(c)

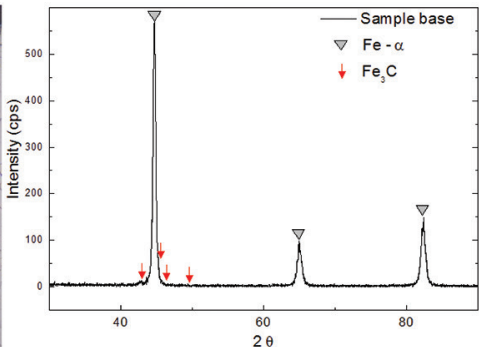

(b)

Figure 1: Sample base: (a) optical microscopy (b), XRD and (c) detailed XRD.

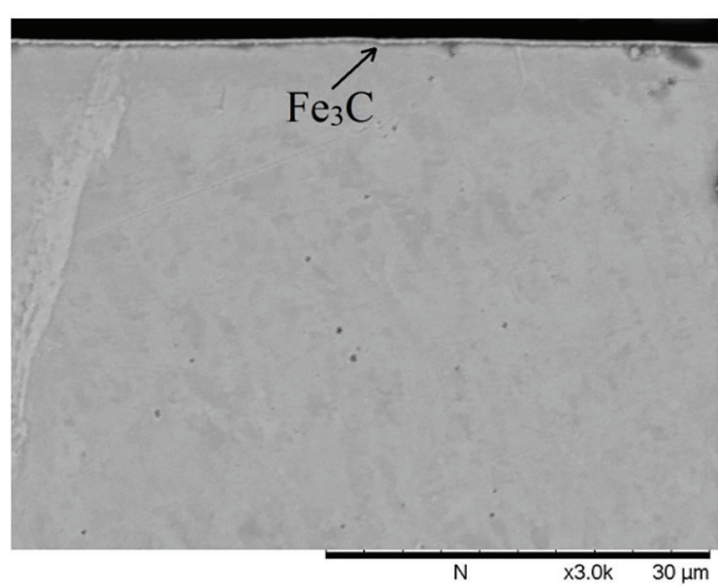

(a)

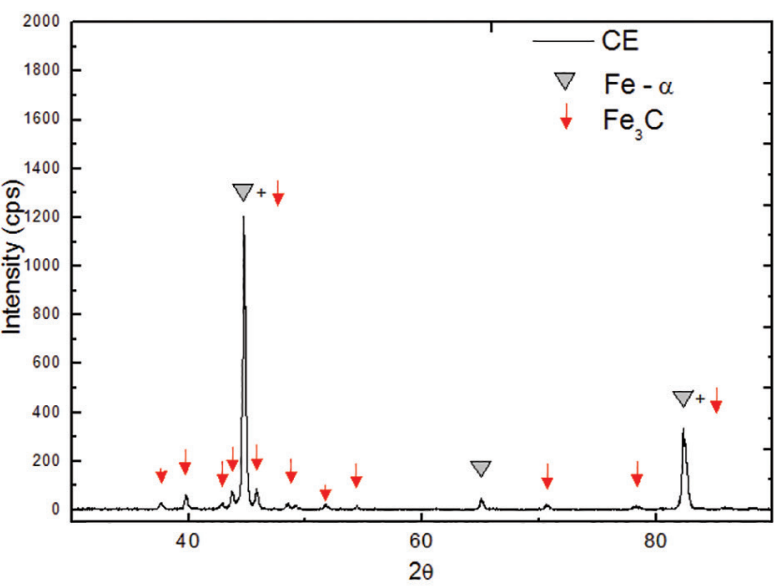

(b)

Figure 2: Sample CE: (a) scanning electron microscopy and (b) XRD.

a diffusion layer. The diffusion zone is mainly formed by $\gamma^{\prime}-\mathrm{Fe}_{4} \mathrm{~N}$ in form of elongated needles, and also by $\alpha$ ' $-\mathrm{Fe}_{16} \mathrm{~N}_{2}$ nitrides in form of short needles, as suggested by ${ }^{19}$ and also reported $\mathrm{in}^{6,20}$. The compound layer is very regular and consists of nitride $\gamma^{\prime}-\mathrm{Fe}_{4} \mathrm{~N}$, as shown in the XRD spectrum of Figure 3 (b).

The XRD analysis of sample N3\% is shown in Figure 4 (b). The diffractogram indicates the presence of Fe- $\alpha$ and discrete peaks corresponding to $\gamma^{\prime}-\mathrm{Fe}_{4} \mathrm{~N}$ and cementite.

Figure 4 (a) shows a micrograph of sample N3\% obtained using SEM. Note that there was no formation of a compound layer, which was already expected according to authors who claim that nitriding with a low nitrogen activity avoids the formation of the compound layer ${ }^{21-23}$.

Figure 5 (a) shows a micrograph of the cross section for the NC treatment. The formation of a compound layer and diffusion zone was observed for this treatment.

It is possible to observe that the compound layer is irregular and contained $\gamma^{\prime}-\mathrm{Fe}_{4} \mathrm{~N}$ and $\varepsilon-\mathrm{Fe}_{3} \mathrm{~N}$ nitrides. Based on how the $\mathrm{Fe}_{3} \mathrm{C}$ carbide was confirmed in the XRD analysis, we may assume that the formation of $\mathrm{Fe}_{3} \mathrm{C}$ occurred. The cementite formation may have been promoted because of the presence of $1.5 \mathrm{vol} . \%$ methane in the gas mixture that could provide a carbon source for the formation of $\mathrm{Fe}_{3} \mathrm{C}$. 


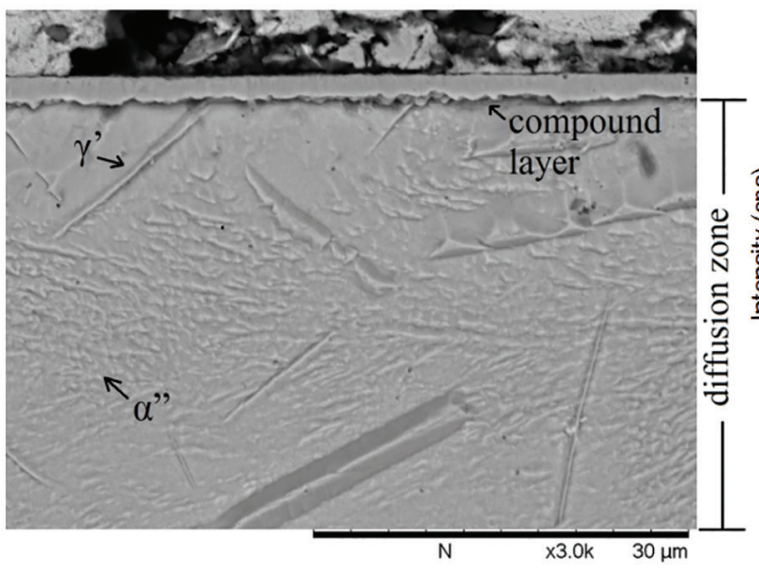

(a)

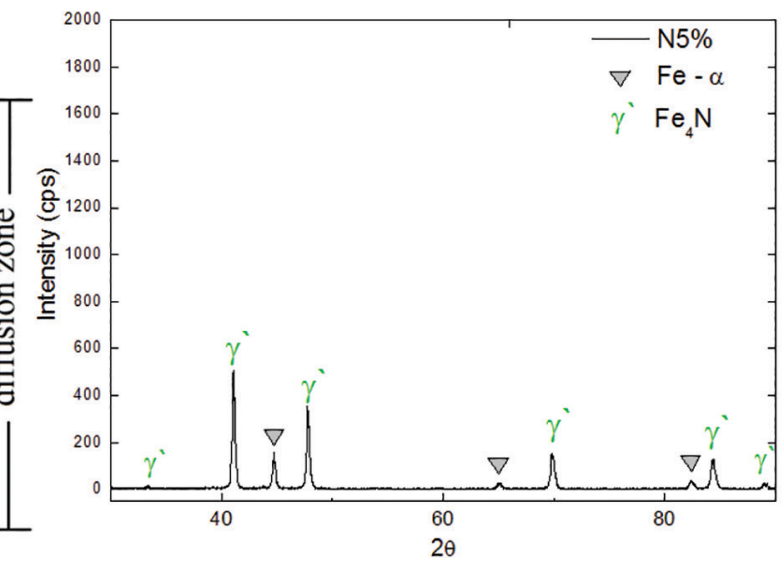

(b)

Figure 3: Sample N5\%: (a) scanning electron microscopy image and (b) XRD.

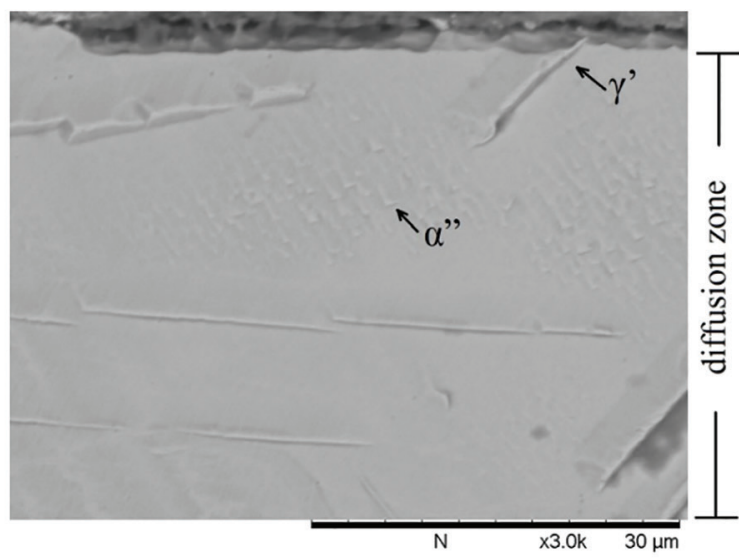

(a)

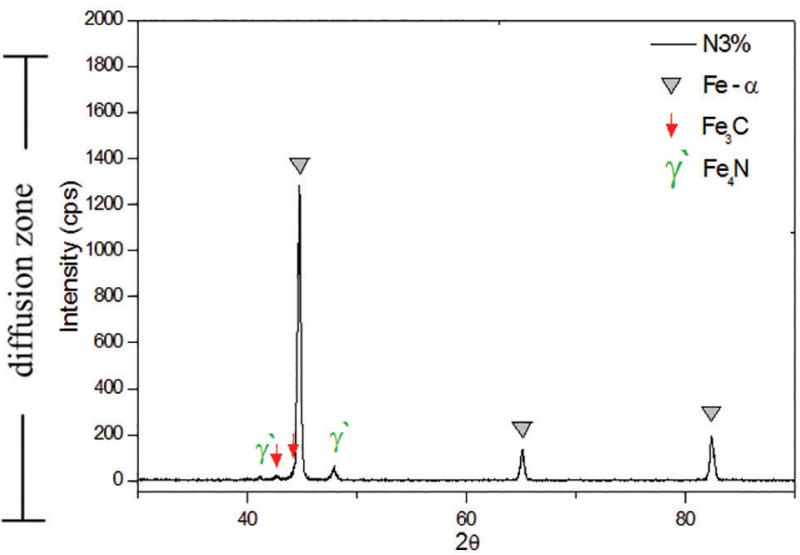

(b)

Figure 4: Sample N3\%: (a) scanning electron microscopy and (b) XRD.

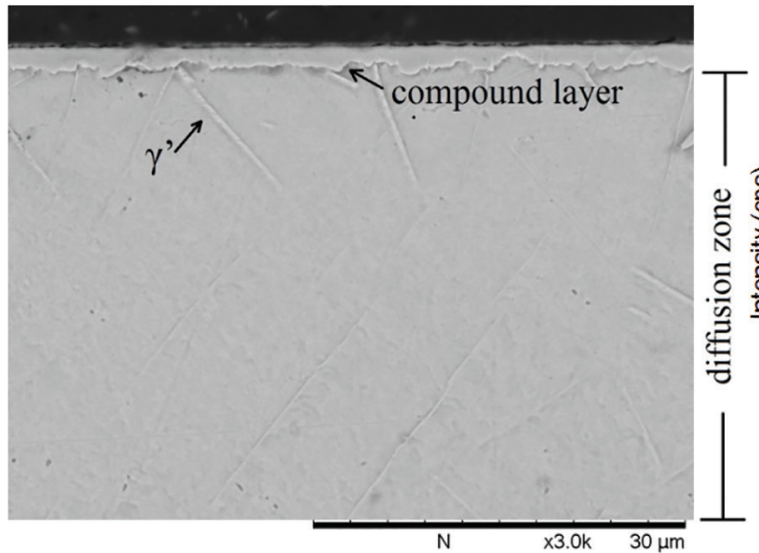

(a)

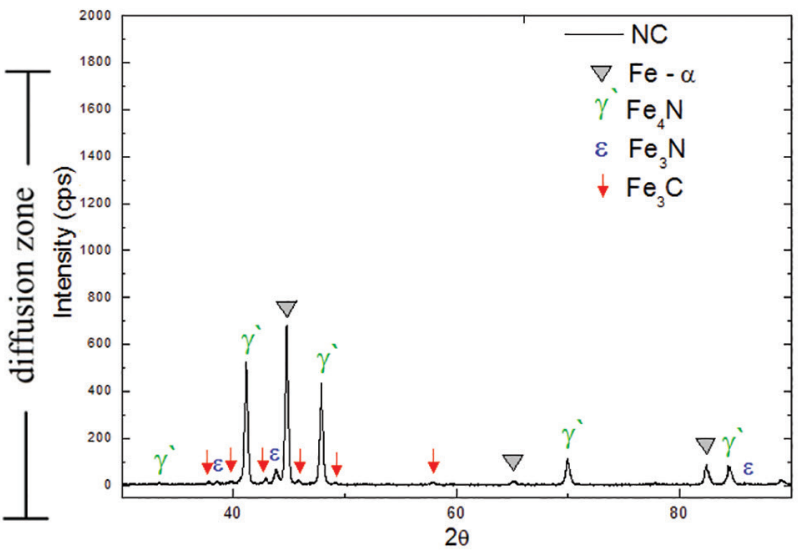

(b)

Figure 5: Sample NC: (a) scanning electron microscopy and (b) XRD. 
The presence of carbon is responsible for the stabilization and increase in the $\varepsilon$ phase in the $\mathrm{Fe}-\mathrm{C}-\mathrm{N}$ phase diagram and a decrease in the phase $\gamma^{\prime}$. According to Figueiredo ${ }^{24}$ the $\gamma^{\prime}-\mathrm{Fe}_{4} \mathrm{~N}$ phase is unstable and tends to evolve into cementite by releasing nitrogen and carbon enrichment.

The diffusion zone of the NC sample is also shown in Figure 5 (a) and consists predominantly of nitride $\gamma^{\prime}-\mathrm{Fe}_{4} \mathrm{~N}$ and a small fraction of $\alpha$ " $-\mathrm{Fe}_{16} \mathrm{~N}_{2}$.

Figure 6 (a) shows a cross section of sample N5\% + CE. It is evident that there are three regions: a very thin outer layer, a compound layer and a diffusion zone.

The outer layer exhibits similar thin and regular characteristics as those observed in the CE treatment, as shown in Figure 2 (a). This layer is easily detached during the metallographic preparation procedure.

It is believed that the outer layer is composed of cementite from the plasma carburizing performed after the nitriding treatment. Furthermore, in this treatment, an increase is observed in the number and intensity of $\mathrm{Fe}_{3} \mathrm{C}$ peaks in the XRD pattern, shown in Figure 6 (b), than those in samples not receiving the carburizing treatment. This may confirm the assumption that a thin layer of cementite formed above the compound layer in the N5\%+CE samples.

The compound layer, shown in detail in Figure 6 (a), is visually the thicker layer among the different treatments performed in this study. Moreover, the layer contains $\gamma^{\prime}-\mathrm{Fe}_{4} \mathrm{~N}$ and $\varepsilon-\mathrm{Fe}_{3} \mathrm{~N}$ nitrides, as observed in the XRD pattern in Figure 6 (b), which also exhibits the presence of $\gamma^{\prime}-\mathrm{Fe}_{4} \mathrm{~N}$ and $\alpha$ "$\mathrm{Fe}_{16} \mathrm{~N}_{2}$ nitrides, which are associated with the diffusion zone.

Sample NC + CE shows the same three layers observed in the treatment N5\% + CE (Figure 7 (a)). The only difference is that the cementite layer is more discreet.

Micrographic analysis of the cross section of sample $\mathrm{N} 3 \%+\mathrm{CE}$ (Figure 8 (a)) revealed the formation of two regions: the outermost layer and the diffusion zone. It is assumed that the layer consists of cementite due to the increased peaks of this compound shown in the sample's
XRD. Still, we observe that the formed layer exhibits some microcracking and has a thickness exceeding that obtained in the CE sample (Figure 2 (a)). Thus, we assume that the $\mathrm{N} 3 \%$ treatment promoted an increase in the thickness of the hardened layer.

The sample diffusion zone in sample N3\%+CE is similar to that formed in sample $\mathrm{N} 3 \%$, and consists of nitrides and $\gamma^{\prime}-\mathrm{Fe}_{4} \mathrm{~N}$ e $\alpha$ ' $-\mathrm{Fe}_{16} \mathrm{~N}_{2}$.

\subsection{Microhardness}

Table 3 shows the results for the surface hardness and the hardening depth obtained for each treatment.

Table 4 shows the layer thickness results obtained using SEM. For the N3\% treatment, no layer thickness was measured, as the sample exhibited no compound layer, which was previously discussed. It is important to note that there were some difficulties in the metallographic preparation of the $\mathrm{N} 3 \%+\mathrm{CE}$ and $\mathrm{NC}+\mathrm{CE}$ samples. The cementite layer was found to peel away from the sample during the polishing step. For this reason, Table 4 shows the layer thicknesses for the $\mathrm{N} 3 \%+\mathrm{CE}$ and $\mathrm{NC}+\mathrm{CE}$ samples determined using 2000 grit sandpaper without any polishing. Because of this, we avoided making comparisons between the layer thicknesses obtained using only sanded samples and those from polished samples. This is because the imaged layer for only a sanded sample is larger than the imaged layer for a sample that has been polished.

Hypothesis testing and estimation of the variances between the top hardness of the sample base and sample CE shows that both are statistically identical with a $95 \%$ probability. This was already observed by Lamim ${ }^{9}$, who attributed this result to the thin layer (in this case $0.45 \mu \mathrm{m}$ ) of cementite, which is a very hard compound, on a ductile substrate which leads to the breakdown of the hardened layer and the concealment of its hardness by the hardness of the substrate. To eliminate the effects of the substrate on the

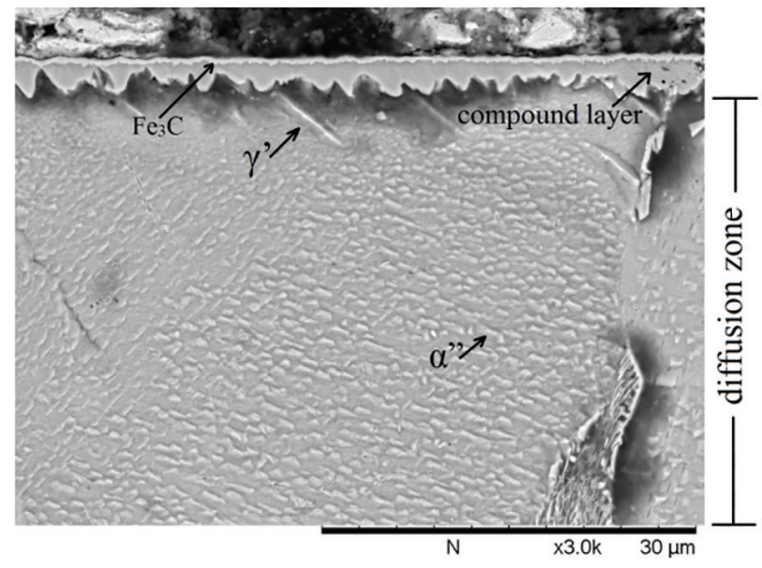

(a)

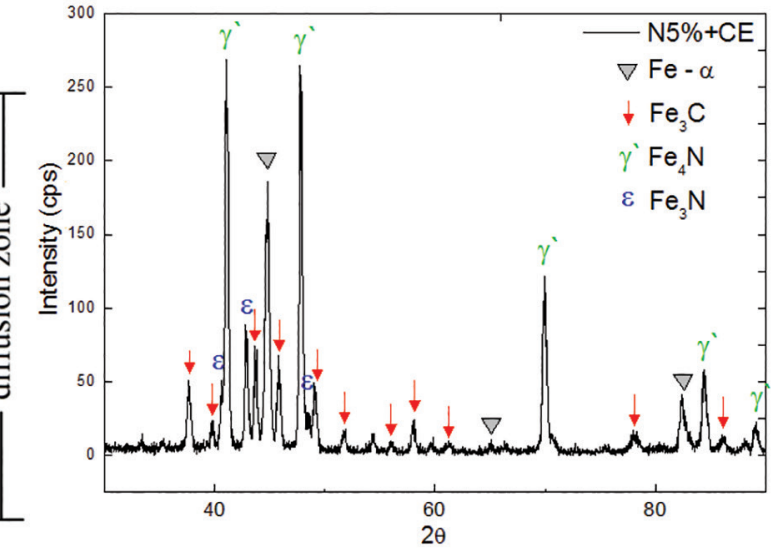

(b)

Figure 6: Sample N5\%+CE: (a) scanning electron microscopy and (b) XRD. 


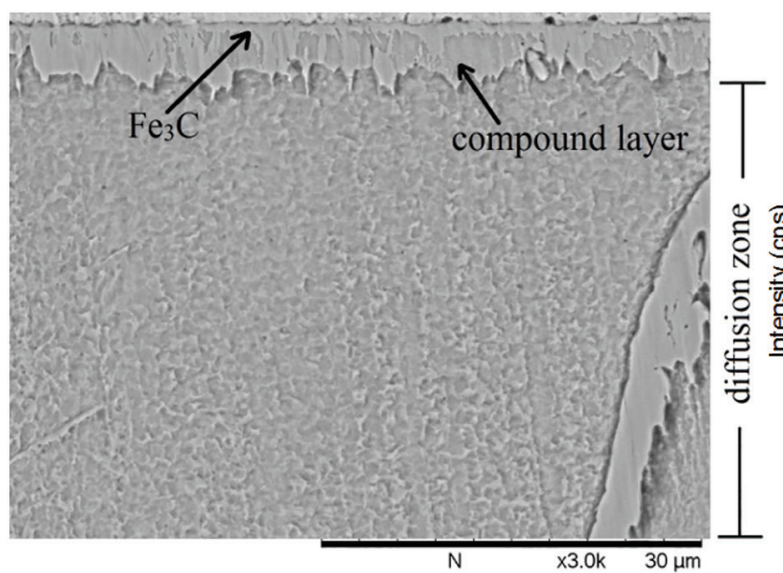

(a)

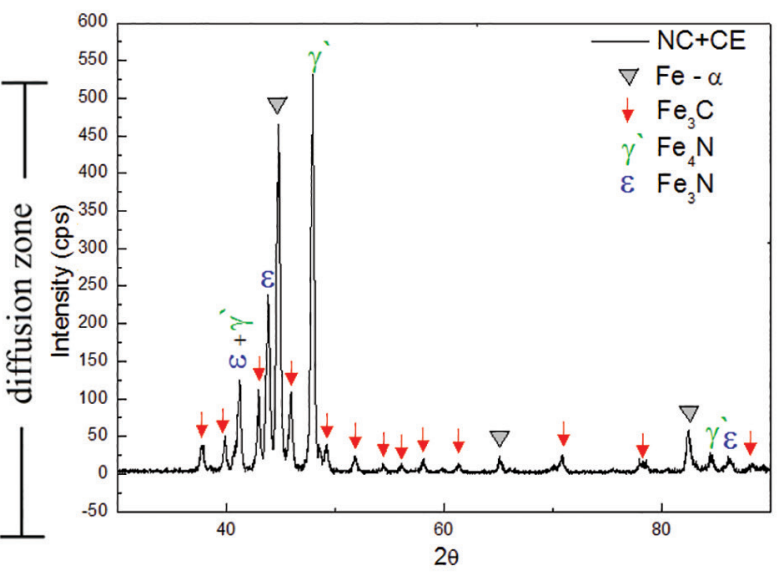

(b)

Figure 7: Sample NC+CE: (a) scanning electron microscopy and (b) XRD.

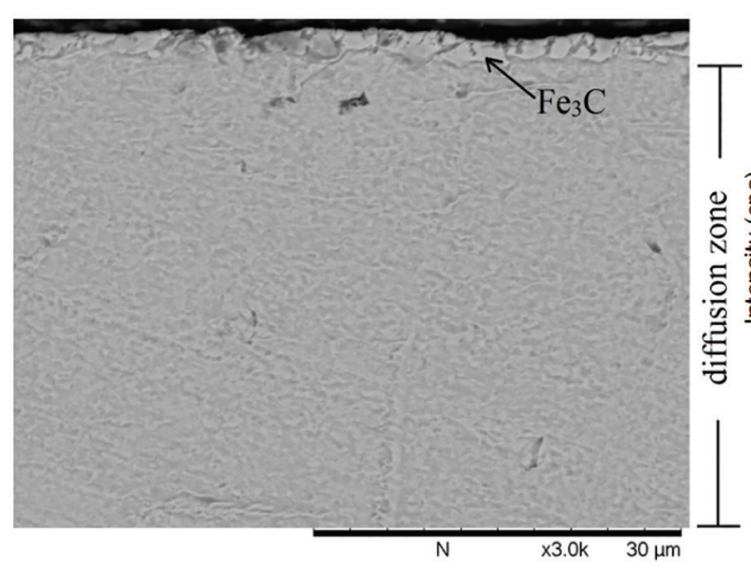

(a)

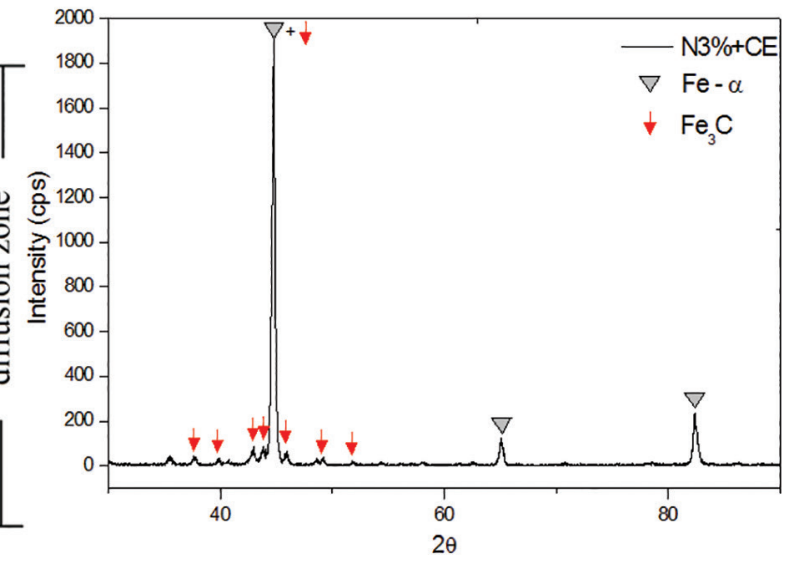

(b)

Figure 8: Sample N3\%+CE: (a) scanning electron microscopy and (b) XRD.

Table 3: Microhardnesses on the top and hardened depth of the studied samples.

\begin{tabular}{lcc}
\hline Treatment & Microhardness top $(\mathrm{HV})$ & Hardening depth $(\mu \mathrm{m})$ \\
\hline Base & $192.4 \pm 5.5$ & - \\
$\mathrm{CE}$ & $206.5 \pm 14.9$ & 100 \\
$\mathrm{~N} 3 \%+\mathrm{CE}$ & $214.6 \pm 12.9$ & 500 \\
$\mathrm{~N} 3 \%$ & $215.7 \pm 10.0$ & 500 \\
$\mathrm{NC}+\mathrm{CE}$ & $224.6 \pm 20.6$ & 800 \\
$\mathrm{NC}$ & $331.1 \pm 22.5$ & 650 \\
$\mathrm{~N} 5 \%+\mathrm{CE}$ & $362.7 \pm 59.7$ & 800 \\
$\mathrm{~N} 5 \%$ & $443.9 \pm 20.9$ & 500 \\
\hline
\end{tabular}

hardness measurement, Jönsson ${ }^{25}$ determined that the ratio of the indentation depth and sample thickness of the layer must be within a critical range, which varies from 0.07 to 0.2 . For the carburized sample, the relation is higher than the critical value, confirming the influence of the substrate hardness values.
Table 4: Thickness of the layers obtained from the treatments.

\begin{tabular}{lll}
\hline Treatment & Layer formed & Layer thickness $(\mu \mathrm{m})$ \\
\hline $\mathrm{CE}$ & Cementite & $0.45 \pm 0.02$ \\
$\mathrm{~N} 5 \%$ & Compound layer & $2.81 \pm 0.26$ \\
$\mathrm{NC}$ & Compound layer & $1.92 \pm 0.43$ \\
& Cementite & $0.58 \pm 0.10$ \\
$\mathrm{~N} 5 \%+\mathrm{CE}$ & Compound layer & $1.73 \pm 1.03$ \\
& Cementite* & $0.95 \pm 0.10$ \\
$\mathrm{NC}+\mathrm{CE}$ & Compound layer* & $3.13 \pm 0.48$ \\
$\mathrm{~N} 3 \%+\mathrm{CE}$ & Cementite* & $1.73 \pm 0.41$
\end{tabular}

*Thickness measurements performed with only the layer sanded (without polishing).

Although the presence of precipitates was not observed in the CE samples, the profiles of the microhardness in the cross-section micrographs are higher than the microhardnesses of the substrate to a depth of $100 \mu \mathrm{m}$ at reliability of $95 \%$. Thus, we believe that for this region, the substrate was solid solution hardened and/or by very small precipitates 
The sample which exhibited the higher surface hardness was the one subjected to the nitriding treatment (N5\%). This may be a result of the significant thickness $(2.81 \mu \mathrm{m} \pm 0.26$ $\mu \mathrm{m})$ and regularity of the formed compound layer.

The results of the top microhardnesses of the sample $\mathrm{NC}+\mathrm{CE}(362.7 \mathrm{HV} \pm 59.7 \mathrm{HV})$ are similar to that presented by Doré ${ }^{26}$, who used the same conditions as in this study and obtained 360.7 HV $\pm 43.3 \mathrm{HV}$. The same was not observed for sample $\mathrm{N} 5 \%+\mathrm{CE}$, which exhibited a hardness obtained of $149.0 \mathrm{HV} \pm 28.6 \mathrm{HV}^{26}$, and differed significantly from the value found in this work: $224.6 \mathrm{HV} \pm 20.6 \mathrm{HV}$.

It is evident that when comparing sample N5\% to samples $\mathrm{NC}, \mathrm{N} 5 \%+\mathrm{CE}$ and $\mathrm{NC}+\mathrm{CE}$, sample $\mathrm{N} 5 \%$ possesses the lowest hardness depth $(500 \mu \mathrm{m})$, but has the highest surface hardness This is attributed to the increased thickness of the compound layer that formed for this treatment compared to the others, confirming the assumption that the greater the thickness of the compound layer, the smaller the diffusion zone ${ }^{27}$.

The sample N3\%+CE exhibited a microhardness of $214.6 \mathrm{HV} \pm 12.9 \mathrm{HV}$, which is statistically identical to sample N3\% (215.7 HV $\pm 10.0 \mathrm{HV})$, despite the first sample having undergone the nitriding process to promote a greater hardness. This result is due to the cementite layer formed during the $\mathrm{N} 3 \%+\mathrm{CE}$ treatment, leading to a very thin layer upon a ductile substrate, resulting in the breakage of the carburized layer and the concealment of hardness by the hardness of the substrate ${ }^{25}$. This situation was mentioned above for sample CE.

The treatments that had the highest hardening depth were the $\mathrm{NC}+\mathrm{CE}$ and the $\mathrm{N} 5 \%+\mathrm{CE}$, which exhibited a hardened depth of $800 \mu \mathrm{m}$. This greater depth of hardening is attributed to the longer hold time that the samples were subjected to the two successive treatments, which provided more time to diffuse nitrogen throughout the sample.

\section{Conclusions}

The highest surface hardness was obtained from the nitriding treatment (N5\%).

For the double treatments of $\mathrm{N} 5 \%+\mathrm{CE}, \mathrm{N} 3 \%+\mathrm{CE}$ and $\mathrm{NC}+\mathrm{CE}$ a fine layer of cementite was observed.

The nitrocarburized depth is $650 \mu \mathrm{m}$. A greater hardening depth was obtained in the samples that were nitrocarburized + carburizing and nitrided + carburized, which achieved a hardened depth of $800 \mu \mathrm{m}$.

\section{Acknowledgements}

The authors would like to thank the Materials Laboratory (LabMat) and Microstructural Characterization (LCM) of the Mechanical Engineering Department, Federal University of Santa Catarina.

\section{References}

1. Çavuşlu F, Usta M. Kinetics and mechanical study of plasma electrolytic carburizing for pure iron. Applied Surface Science. 2011;257(9):4014-4020.

2. Çetin A, Tek Z, Öztarhan A, Artunç N. A comparative study of single and duplex treatment of martensitic AISI 420 stainless steel using plasma nitriding and plasma nitriding-plus-nitrogen ion implantation techniques. Surface and Coatings Technology. 2007;20(19-20):8127-8130.

3. Bendo T, Maliska AM, Acuña JJS, Binder C, Demetrio KB, Klein AN. Nitriding of surface Mo-enriched sintered iron: Structure and morphology of compound layer. Surface and Coatings Technology. 2014;258:368-373.

4. Klein AN, Cardoso RP, Pavanati HC, Binder C, Maliska AM, Hammes G, et al. DC Plasma Technology Applied to Powder Metallurgy: an Overview. Plasma Science and Technology. 2013;15(1):70-81.

5. De Mello JDB, Binder C, Binder R, Klein AN. Effect of nature of nitride phases on microabrasion of plasma nitrided sintered iron. Tribology-Materials, Surfaces \& Interfaces. 2010;4(4):191-196.

6. Bendo T, Pavanati HC, Klein AN, Martinelli AE, Maliska AM. Plasma Nitriding of Surface Mo-Enriched Sintered Iron. ISRN Materials Science. 2011;2011:8p.

7. Hosseini SR, Ashrafizadeh F. Accurate measurement and evaluation of the nitrogen depth profile in plasma nitrided iron. Vacuum. 2009;83(9):1174-1178.

8. Maliska AM. Influência de elementos de liga e do oxigênio no processo de nitretação por plasma em aços sinterizados. [Doctoral thesis]. Florianópolis: Federal University of Santa Catarina; 1995.

9. Lamim TS, Benardelli EA, Binder C, Klein AN, Maliska AM. Plasma carburizing of sintered pure iron at low temperature. Materials Research. 2015;18(2):320-327.

10. Sun Y. Kinetics of low temperature plasma carburizing of austenitic stainless steels. Journal of Materials Processing Technology. 2005;168(2):189-194.

11. Sun Y. Tribocorrosion behavior of low temperature plasma carburized stainless steel. Surface and Coatings Technology. 2013;228(Suppl 1):s342-s348.

12. Scheuer CJ, Cardoso RP, Zanetti FI, Amaral T, Brunatto SF Low-temperature plasma carburizing of AISI 420 martensitic stainless steel: Influence of gas mixture and gas flow rate. Surface and Coatings Technology. 2012;206(24):5085-5090.

13. Souza RM, Ignat M, Pinedo CE, Tschiptschin AP. Structure and properties of low temperature plasma carburized austenitic stainless steels. Surface and Coatings Technology. 2009;204(67):1102-1105.

14. Baek JM, Cho YR, Kim DJ, Lee KH. Plasma carburizing process for the low distortion of automobile gears. Surface and Coatings Technology. 2000;131(1-3):568-573.

15. Siriwardane H, Pringle OA, Newkirk JW, James WJ. Microstructure and physical properties of iron carbide films formed by plasma enhanced chemical vapor deposition. Thin Solid Films. 1996;287(1-2):8-15. 
16. Li JL, O'Keefe TJ, James WJ. Iron carbide films formed by plasma deposition and plasma carburizing. Materials Science and Engineering: B. 1990;7(1-2):15-23.

17. Carpene E, Schaaf P. Formation of Fe3C surface layers by laser plasma cementation. Applied Physics Letters. 2002;80:891-893.

18. Schaaf P, Kahle M, Carpene E. Reactive laser plasma coating formation. Surface and Coatings Technology. 2005;200(14):608-611.

19. Metin E, Inal OT. Formation and growth of iron nitrides during ion-nitriding. Journal of Materials Science. 1987;22(8):2783-2788.

20. Gontijo LC, Machado R, Miola EJ, Casteletti LC, Nascente PAP. Characterization of plasma-nitrided iron by XRD, SEM and XPS. Surface and Coatings Technology. 2004;183(1):10-17.

21. Mittemeijer EJ, Slycke JT. Chemical potentials and activities of nitrogen and carbon imposed by gaseous nitriding and carburising atmospheres. Surface Engineering. 1996;12(2):152-162.
22. Mittemeijer EJ, Somers MAJ. Thermodynamics, kinetics, and process control of nitriding. Surface Engineering. 1997;13(6):483-497.

23. Jack DH, Jack KH. Carbides and nitrides in steel. Materials Science and Engineering. 1973;11(1):1-27.

24. Figueiredo RS. Análise da superfície em aços nitretados por espectroscopia Mössbauer. [Dissertation]. Florianópolis: Federal University of Santa Catarina; 1991.

25. Jönsson B, Hogmark S. Hardness measurement of thin films. Thin Solid Films. 1984;114(3):257-269.

26. Doré M. Nitretação-cementação e carbonitretação-cementação a plasma em baixas temperaturas de ferro puro sinterizado. [Final paper]. Florianópolis: Federal University of Santa Catarina; 2013.

27. Edenhofer B. Physical and metallurgical aspects of ionitriding - Part 2. Heat treatment of metals. 1974;2:59-67. 